\title{
The Risk of Falling in Elderly Increased with Age Growth and Unaffected by Gender
}

\author{
Wilson Susilo*, Yenni Limyati**, Decky Gunawan**** \\ *Faculty of Medicine Maranatha Christian University \\ Jl. Prof. Drg. Suria Sumantri MPH No. 65 Bandung 40164 Indonesia \\ ** Physical Medicine and Rehabilitation Department Immanuel Hospital Bandung \\ Jl. Kopo No. 161 Bandung 40234 Indonesia \\ **** Department of Physiology Faculty of Medicine Maranatha Christian University \\ Jl. Prof. Drg. Suria Sumantri MPH No. 65 Bandung 40164 Indonesia \\ Email: wilsonsusilo@yahoo.com
}

\begin{abstract}
Elderly people are a group of people with age of 60 and above. Studies in United States showed one-third of elderly people experienced fall in their houses and one-forty of them need bedrest in hospital. Falling can cause physical and mental injury. Physical injury manifests as fracture, hematoma, bruises, and dislocation, and mental injury manifests as lack of self esteem. This study aimed to examine the relation between age and gender on risk of fall on elderly people. This is a cross-sectional analytical study involving 23 elderly people from Tulus Kasih Elderly Home that met the inclusion criteria. Risk of fall were checked with Timed Up and Go Test. The data acquired were analyzed with chi-square with $\alpha=0,05$. As results, age significantly affected risk of fall $(p=0.019)$ but gender did not $(p=0.265)$. We concluded the risk of falling is increased with age and unaffected by gender.
\end{abstract}

Keywords : age, gender, risk of fall, timed up and go test 


\title{
Risiko Jatuh pada Lansia Meningkat dengan Bertambahnya Usia dan Tidak Dipengaruhi Jenis Kelamin
}

\author{
Wilson Susilo", Yenni Limyati**², Decky Gunawan ${ }^{* * *}$ \\ *Fakultas Kedokteran, Universitas Kedokteran Maranatha \\ ***Bagian Skills Lab/Kedokteran Fisik dan Rehabilitasi, Fakultas Kedokteran, \\ Universitas Kristen Maranatha/RS Immanuel \\ *** Bagian Fisiologi, Fakultas Kedokteran, Universitas Kristen Maranatha \\ Fakultas Kedokteran, Universitas Kristen Maranatha \\ Jl. Prof. Drg. Suria Sumantri MPH No. 65 Bandung 40164 Indonesia \\ Email : wilsonsusilo@yahoo.com
}

\begin{abstract}
Abstrak
Lanjut usia (lansia) adalah kelompok penduduk yang berusia 60 tahun ke atas. Menurut penelitian di Amerika Serikat sepertiga lansia pernah mengalami jatuh dan seperempatpuluhnya perlu mendapatkan penanganan di rumah sakit. Jatuh bisa menyebabkan cedera fisik dan psikologis. Cedera fisik dapat berupa fraktur, hematoma, memar, dan dislokasi dan cedera psikologi berupa rasa tidak percaya pada diri sendiri. Tujuan penelitian ini adalah untuk melihat pengaruh usia dan jenis kelamin terhadap risiko jatuh pada lansia. Penelitian ini menggunakan metode survei analitik dengan rancangan penelitian cross sectional, melibatkan 23 subjek lansia dari Panti Jompo Tulus Kasih yang memenuhi kriteria inklusi. Risiko jatuh diperiksa dengan Timed Up and Go Test. Data yang diperoleh dianalisis dengan uji chi-square dengan $\alpha=0,05$. Dari penelitian ini didapatkan usia mempengaruhi risiko jatuh $(\mathrm{p}=0.019)$,namun jenis kelamin tidak $(\mathrm{p}=0.265)$. Dapat disimpulkan bahwa risiko jatuh meningkat seiring dengan bertambahnya usia dan tidak dipengaruhi oleh jenis kelamin.
\end{abstract}

Kata kunci : jenis kelamin, risiko jatuh, timed up and go test, usia 
Research Article

\section{Pendahuluan}

Lanjut usia (lansia) adalah kelompok penduduk yang berusia 60 tahun ke atas. Secara biologis lanjut usia ialah orang yang mengalami proses penuaan, yang ditandai dengan penurunan fungsi organ-organ, termasuk tulang dan otot. Penurunan massa tulang dan otot akan menyebabkan penurunan kemampuan seseorang untuk menjaga keseimbangan yang dapat menyebabkan seseorang bisa terjatuh. ${ }^{1}$

Jatuh adalah suatu keadaaan yang terjadi tiba-tiba dan tanpa disengaja yang menyebabkan perubahan posisi seseorang berada di tempat lebih rendah dengan posisi yang duduk atau terbaring. ${ }^{1}$ Di dunia sebanyak $30 \%$ lansia pernah mengalami jatuh. Penelitian di Amerika Serikat sepertiga lansia pernah mengalami jatuh dan seperempat puluhnya perlu mendapatkan perawatan di rumah sakit. Pada institusi dan rumah perawatan, lebih dari $50 \%$ kejadian jatuh setiap tahun, $40 \%$ di antaranya mengalami jatuh berulang. Kejadian jatuh terlihat berbanding lurus dengan peningkatan usia. Jatuh dianggap sebagai konsekuensi alami dari menjadi tua, tetapi sesungguhnya jatuh bukan bagian normal dari proses penuaan. ${ }^{2}$

Jenis kelamin digolongkan menjadi laki-laki dan perempuan. Perempuan pada usia lanjut akan mengalami menopause, yang akan mengakibatkan kekurangan hormon estrogen. Kepadatan tulang sangat dipengaruhi oleh sistem hormon dalam tubuh. Kelainan bentuk tubuh dikarenakan berkurangnya kepadatan tulang yang meningkatkan risiko jatuh sering terjadi pada perempuan. ${ }^{3}$

Jatuh merupakan kegagalan seseorang untuk mempertahankan keseimbangan badan untuk berdiri. Keseimbangan dapat dicapai dengan kerja dari otot-otot dan organ penyeimbang untuk mempertahankan posisi tubuh. Kelemahan otot dan terganggunya organ penyeimbang seperti mata dan telinga tengah yang terjadi pada lansia dapat menyebabkan peningkatan risiko jatuh. Jatuh akan menyebabkan cedera fisik maupun psikologis. Cedera fisik akibat jatuh bisa berupa fraktur, dislokasi, memar, hemarthrosis, dan subdural hematom. Kejadian jatuh berulang dapat menyebabkan hilangnya kepercayaan diri lansia untuk dapat melakukan aktivitas seharihari tanpa bantuan orang lain. ${ }^{4}$

Jatuh dapat dihindari dengan lingkungan dan pengawasan yang baik. Lingkungan untuk lansia memerlukan lantai yang datar, kering, dan tidak licin, tempat tidur dan WC yang tidak terlalu rendah, serta penerangan yang baik. Aktivitas harian dari lansia seperti naik turun tangga sebisa mungkin untuk dihindari. Pengetahuan pengawas lansia terhadap risiko jatuh dari seorang lansia merupakan suatu hal yang penting. Pengetahuan ini dapat menjadi suatu pertimbangan untuk memberi pengawasan lebih pada lansia dengan risiko jatuh yang tinggi. Berkurangnya kejadian jatuh pada lansia akan meningkatkan kualitas hidup lansia yang semakin bertambah. ${ }^{5}$ 
Research Article

\section{Metode}

Penelitian survei analitik dengan rancangan penelitian cross sectional yaitu cara pendekatan, observasi atau pengumpulan data dilakukan pada saat yang bersamaan. Subjek penelitian adalah 23 orang lansia dari Panti Jompo Tulus Kasih yang memenuhi kriteria yang telah ditentukan, antara lain: usia $\geq 60$ tahun, dapat berjalan tanpa alat bantu minimal 6 meter, tidak mengalami gangguan penglihatan dan pendengaran total.

Data yang diambil adalah tekanan darah, nadi, jenis kelamin, usia, dan hasil "Timed $U p$ and Go Test" sebagai skrining risiko jatuh. Prosedur "Timed Up and Go" dilakukan dengan cara subjek duduk pada kursi setinggi $50 \mathrm{~cm}$, pinggul menempel pada sandaran kursi, subjek melihat lintasan sejauh 3 meter, dengan instruksi "mulai" maka subjek berdiri dan mulai berjalan sesuai garis yang ditentukan dan kembali berjalan sejauh 3 meter dari garis yang ditentukan lalu kembali duduk. ${ }^{6,7}$ Selama melakukan Timed Up and Go Test subjek didampingi pengawas tetapi tidak boleh dibantu berjalan. Parameter yang diukur adalah waktu yang diperlukan dari instruksi "mulai" sampai duduk kembali, dikategorikan berdasarkan Normal ( $\leq 10$ detik), Cukup (11 - 20 detik), Bermasalah $\left(21-30\right.$ detik). ${ }^{8}$

Data yang diperoleh dianalisis secara univariat untuk melihat gambaran usia dan jenis kelamin kemudian dianalisis secara bivariat dengan menggunakan uji chi-square dan perhitungannya menggunakan perangkat lunak komputer. Pada uji chi-square, derajat kepercayaan yang digunakan adalah $\alpha=0,05$. Jika $p$-value lebih kecil dari $\alpha(p<0,05)$, artinya terdapat hubungan yang bermakna (signifikan) antara kedua variabel yang diteliti. Bila $p$-value lebih besar dari $\alpha(p>0,05)$, artinya tidak terdapat hubungan antara kedua variabel yang diteliti.

\section{Hasil}

Karakteristik usia terhadap risiko jatuh dapat dilihat pada tabel 1, sedangkan karakteristik jenis kelamin terhadap risiko jatuh dapat dilihat pada tabel 2.

Tabel 1 menunjukkan 48\% lansia dalam kategori Normal, 52\% lansia dalam kategori Cukup. Pada kategori Normal sebanyak 39\% dari usia 60-69 tahun dan sebanyak 9\% dari usia 70-79 tahun. Pada kategori Cukup sebanyak 17\% dari usia 60-69 tahun, sebanyak 35\% dari usia 70-79 tahun. Hal ini menunjukkan usia 60-69 tahun memiliki persentase terbesar dalam kategori Normal, usia 70-79 tahun memiliki persentase terbesar dalam kategori Cukup. Tidak didapatkan pada kategori bermasalah dan usia 80-89 tahun sehingga risiko jatuh dikategorikan pada Normal dan Cukup, dan usia dikategorikan pada usia 60-69 tahun dan 70-79 tahun. 
Tabel 1 Karakteristik Usia terhadap Risiko Jatuh

\begin{tabular}{llcc}
\hline Karakteristik & \multicolumn{2}{l}{ Risiko Jatuh (Timed Up and Go Test) } & p \\
\cline { 2 - 3 } Usia & Normal & Cukup & \\
$\mathbf{6 0 - 6 9}$ tahun & $9(39 \%)$ & $4(17 \%)$ & \\
$\mathbf{7 0 - 7 9}$ tahun & $2(9 \%)$ & $8(35 \%)$ & 0,019 \\
& & & \\
\hline Total & $\mathbf{1 1 ( 4 8 \% )}$ & $\mathbf{1 2 ( 5 2 \% )}$ & \\
\hline
\end{tabular}

Dari hasil analisis data statistik usia terhadap risiko jatuh diperoleh nilai p untuk uji chisquare adalah 0,019 . Nilai $\mathrm{p} \leq 0,05$ menunjukkan hasil pengujian dinyatakan signifikan. Hal ini menunjukkan bahwa antara usia dan risiko jatuh memiliki hubungan yang signifikan.

Tabel 2 Karakteristik Jenis Kelamin Terhadap Risiko Jatuh

\begin{tabular}{llcc}
\hline Karakteristik & \multicolumn{2}{l}{ Risiko Jatuh (Timed Up and Go Test) } & p \\
\cline { 2 - 3 } Jenis Kelamin & Normal & Cukup & \\
Laki-laki & $8(35 \%)$ & $6(26 \%)$ & \\
Perempuan & $3(13 \%)$ & $6(26 \%)$ & \\
& & & \\
\hline Total & $\mathbf{1 1 ( 4 8 \% )}$ & $\mathbf{1 2 ( 5 2 \% )}$ & \\
\hline
\end{tabular}

Tabel 2 menunjukkan 48\% dalam kategori Normal, sebanyak 35\% laki-laki dan sebanyak $13 \%$ perempuan. Dalam kategori Cukup sebanyak 52\%, terdiri atas 26\% laki-laki dan $26 \%$ perempuan. Hal ini menunjukkan laki-laki memiliki persentase yang lebih besar pada kategori Normal, dan pada kategori Cukup persentase laki-laki dan perempuan sama.

Dari hasil analisis data statistik jenis kelamin terhadap risiko jatuh diperoleh nilai $\mathrm{p}$ untuk uji chi-square adalah 0,265 . Nilai $\mathrm{p} \geq 0,05$ menunjukkan hasil analisis pengujian adalah tidak signifikan. Hal ini menunjukkan bahwa antara jenis kelamin dan risiko jatuh tidak memiliki hubungan yang signifikan.

\section{Diskusi}

Hasil analisis penelitian ini menunjukkan bahwa pengaruh usia terhadap risiko jatuh adalah signifikan ( $\mathrm{p}=0,019$; OR=9), yang berarti subjek pada usia 70-79 tahun sembilan kali lebih berisiko jatuh dari usia 60-69 tahun. Semakin tinggi usia seseorang akan lebih berisiko mengalami masalah kesehatan karena adanya faktor-faktor penuaan lansia sehingga mengalami perubahan baik fisik, ekonomi, psikologikal, kognitif, dan spiritual. ${ }^{4}$ Ditinjau dari aspek fisik pada lansia terjadi penurunan kekuatan otot dan massa tulang, dan keterbatasan rentang gerak 


\section{Research Article}

sendi. ${ }^{9}$ Hal ini sesuai dengan penelitian terdahulu yang dilakukan Syarifah Nurhayati tahun 2014 yang menyatakan usia lanjut berhubungan signifikan dengan disabilitas fisik $(p=0,015)$; dan probabilitas atau risiko untuk terjadinya disabilitas fisik didapatkan $\mathrm{OR}=3,665$, dapat diartikan bahwa semakin meningkat usia seseorang mempunyai risiko 3,665 kali untuk mengalami kejadian disabilitas fisik. ${ }^{10}$

Pada penelitian ini didapatkan perempuan memiliki risiko jatuh lebih tinggi dari lakilaki. Dapat dilihat dari 9 perempuan sebanyak 6 orang (67\%) masuk kategori Cukup dan sebanyak 3 orang (33\%) masuk dalam kategori Normal, dan laki-laki sejumlah 14 orang, sebanyak 6 orang (43\%) masuk dalam kategori Cukup dan sebanyak 8 orang (57\%) masuk dalam kategori Normal. Meskipun hasil menunjukkan secara statistik tidak signifikan namun secara klinis perempuan lebih berisiko jatuh dari laki-laki. Hal ini dikarenakan kekurangan estrogen pada perempuan lanjut usia menyebabkan osteoklastogenesis menurun dan terjadi kehilangan massa tulang. Kehilangan massa tulang bisa menyebabkan perubahan postur tubuh yang memengaruhi risiko jatuh. Hasil secara statistik tidak signifikan dipengaruhi oleh beberapa faktor, seperti jumlah subjek yang terbatas dan penyakit yang diderita.

Perempuan lebih berisiko jatuh dari laki laki sesuai dengan penelitian terdahulu yang dilakukan Lingga Yogi Prasetya, Ari Wibawa, dan I Nyoman Adiputra tahun 2014, didapatkan hasil $13(81,3 \%)$ laki-laki dan $21(86,7 \%)$ perempuan yang mengalami kifosis, sehingga perubahan postur menyebabkan risiko jatuh perempuan lebih tinggi dari laki-laki.

Keterbatasan penelitian ini adalah penelitian menggunakan desain cross sectional sehingga hanya dapat menunjukkan hubungan korelasi bukan kausalitas, pengambilan sampel tidak mewakili seluruh populasi.

\section{Simpulan}

Berdasarkan hasil penelitian dan pembahasan, maka dapat ditarik simpulan bahwa usia memengaruhi risiko jatuh, pada usia 70-79 tahun risiko jatuh lebih besar dari usia 60-69 tahun dan jenis kelamin tidak memengaruhi risiko jatuh.

\section{Daftar Pustaka}

1. Nugroho W. Keperawatan Gerontik \& Geriatrik. Jakarta: EGC; 2008.

2. Farabi A. Hubungan Tes "Timed Up And Go" Dengan Frekuensi Jatuh Pada Lansia.;2007. h.5-6

3. Kawiyana IK. . Osteoporosis patogenesis diagnosis dan penanganan terkini. J Peny Dalam. 2009; 10(2):158-9

4. Ediawati E. Gambaran Tingkat Kemandirian Dalam Activity of Daily Living (ADL) dan Resiko Jatuh pada Lansia di Panti Sosial Tresna Wredha Budi Mulia 01 dan 03 Jakarta Timur; 2012. h.10

5. Susanti H. Pengkajian dan Pencegahan Jatuh Pada Lansia; 2009. h.4

6. STEADI (Stop Elderly, Accidents, Deaths, and Injuries. Retrieved january 27, 2016, from U.S Department of Health \& Human Services. Available at: http://www.cdc.gov/steadi/index.html.

7. Podsiadlo D, Richardson S. The Time "up and go": a test of basic functional mobility of frail elderly person. J. Am Geriatric Soc.1991;39(2):142-8 


\section{Research Article}

8. Barry EGR. Is the Timed Up and Go test a useful predictor of risk of falls in community dwelling older adults: a systematic review and meta-analysis. Dublin, Republic of Ireland; 2014.

9. Jusnimar. Analisis Praktik Klinik Keperawatan Kesehatan Masyarakat Perkotaan Pada Nenek G dengan Masalah Risiko Jatuh di Wisma Bungur Sasana Wisma Wherda Karya Bhakti; 2014. h.45

10. Nurhayati S. Analisis Faktor Risiko Kejadian Disabilitas Fisik Pada Lansia di Kecamatan Punung Kabupaten Pacitan; 2014.h.107 